\title{
THE ESSENCE AND ROLE OF ECOLOGICALLY SAFE AGRICULTURAL LAND USE IN AGRICULTURE
}

\author{
Kupriyanchyk IP, Doctor of Economics \\ Email: Kupriyanchik@ukr.net \\ National University of Life and Environmental Sciences of Ukraine
}

\begin{abstract}
The article focuses on the relationship between economic development and environmental security.

With regard to agricultural land use, ensuring environmental security involves optimizing the organization of land use and land use process on the basis of environmental restrictions on environmental pollution and agricultural products. First of all, in accordance with environmental constraints, the possibilities of exploitation of natural resources and taking into account the peculiarities of agroecosystems (natural and climatic conditions, water resources, terrain, land and soil structure, land erosion, etc.) are determined to solve food security problems. On their basis, ecologically balanced operation of agroecosystems is carried out through the formation of ecologically safe land uses, which provide for the optimization of economic activity of agricultural producers, taking into account environmental constraints.

The article clarifies the essence and significance of ecologically safe agricultural land use in agriculture, proposes an approach to defining the essence of ecologically safe agricultural land use as a process of land use in the agricultural sector of the economy, which prevents the danger to human health, degradation of land resources, as well as their resilience to environmental threats and risks. The role of ecologically safe agrarian land use in ensuring sustainable development of rural areas and directions of influence of interaction of ecological and economic components of safety of agrarian land use are defined
\end{abstract}


Keywords. Ecologically safe agricultural land use, agriculture, economic development, sustainable development.

Formulation of the problem. Socio-economic development of any country in the modern world is determined primarily by food security, in connection with which the problem of reproduction of agricultural resources and sustainable development of the agricultural sector of the economy as a whole is an important part of public policy.

Given the current realities of economic relations, marked by the transformation of socio-economic relations, the institution of property rights, production structures, special attention needs to be paid to further improving relations in the field of land use. At the same time, the use of land resources as the main means of agricultural production and the location of productive forces in rural areas should be based on formal institutions and regulate land relations in the rights of the business entity own, use and dispose of land, as well as its responsibilities to ensure the protection and reproduction of land, preservation of their fertility, adhere to environmental norms and standards in the field of agricultural land use. Therefore, agricultural policy should be formed taking into account the requirements for environmentally friendly use of agricultural land, reproduction of soil fertility, prevention of degradation and deterioration of quality characteristics [13].

Thus, understanding the essence and defining the role of ecologically safe agricultural land use are relevant in the context of sustainable development of rural areas.

The purpose of the article. To substantiate the relationship between economic development and environmental safety and to clarify the essence and importance of environmentally friendly agricultural land use in agriculture.

Presenting main material. The need to address environmental issues is due to the significant number of environmental and social hazards that may arise as a result of intensive agricultural land use. Therefore, objectively, an important and 
effective tool for sustainable development, in our opinion, is the formation of a system of environmentally friendly agricultural land use, which can be a guide to ensure proper living standards, agro-ecosystems and should satisfy, above all, safe business activities. (picture 1).

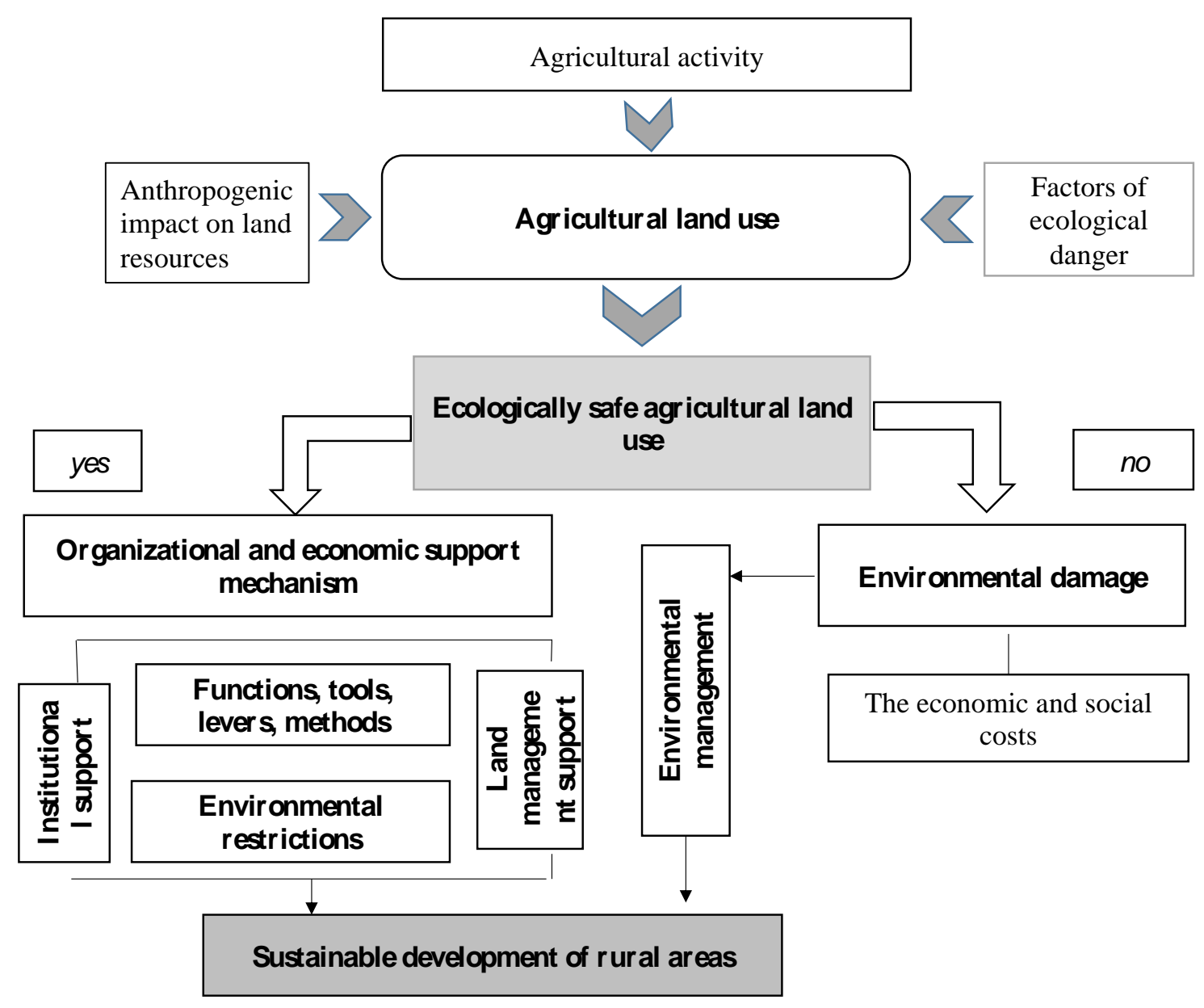

Picture 1. The role of environmentally friendly agricultural land use in ensuring sustainable development of rural areas

Source: adapted by the author for [6;22].

In fact, it is the ability to counteract the effects of adverse environmental factors, including natural disasters, as well as the ability to prevent or minimize industrial downturns. At the same time, balanced development in the context of rural 
development involves the protection of certain amounts of particularly valuable agricultural land or, in the case of their reduction, maintenance (increase) of agricultural production, resource potential of land.

Thus, sustainable development of rural areas in market conditions is impossible without the formation of environmentally friendly agricultural land use. In general, the content of the system of ecologically safe agricultural land use should include balanced distribution and efficiency of land use in the structure of the general agroecological system, support, protection (prevention of degradation processes) and improvement of primary qualities of agricultural lands (increase of soil fertility).

Environmental safety is often used in the sense of protection, understanding it as a condition in which the appearance of hidden dangers of a particular object is inhibited or their adverse effects are significantly reduced. In addition, security involves the implementation of certain initiative and effective measures. Therefore, the provisions of security theory are focused on resistance to threats, or otherwise - on the timely detection of potential hazards and the implementation of a system of measures to prevent negative environmental indications of such threats [7]. In order to ensure environmentally friendly agricultural land use, it is necessary to introduce a number of measures to organize safe regimes of land use, taking into account the biological characteristics of soils and plants, as well as natural and climatic conditions of the territories [20]. Also a necessary condition for ensuring the protection of agricultural land from possible environmental threats and risks is mandatory compliance with the requirements for the rational organization of land and the structure of sown areas. The issue of environmental safety implies that the organization of agricultural land use should take into account all factors influencing the state of land and the environment, as well as the sustainable development of agroecosystems in general [8, p. 167].

The next stage in the development of the concept of security is due to the rapid development of technologies used by man in the process of life, in which the 
concept of security is technogenic. Finally, the current stage, in addition to these features, includes another, new feature - environmental [1]. Thus, the evolution of the identified threats to the safe functioning and life of the individual and society as a whole eventually leads to the emergence of environmental threats in the field of land use and forms such a concept as "environmentally friendly agricultural land use."

At the same time, the views of a number of scholars on the formulation of this definition are quite diverse, which has led to differences in approaches to the interpretation of the content of this term.

In addition, ensuring the process of environmentally safe land use involves taking into account a number of other concepts that are somehow related to this category, in particular: "rational land use", "ecologically balanced land use", "sustainable land use", "balanced land use" and so on. It is also worth noting the use of a number of, in our opinion, "synonyms" of the term land use.

For example, in his work OS Budziak [4] defines the concept of environmentally friendly land use as "territorial and spatial use of land in the balance-cycle process of land-user relations, within the capacity of ecosystems, under conditions that guarantee their protection and prevention of irreversible environmental processes on land." L.Ye. Kupinets and OV Zhavnerchyk [11] define the ecological safety of agricultural land use as "a process that minimizes the impact of controlled hazards (anthropogenic, natural-destructive: erosion, karst, etc.) and resistance to uncontrolled (extreme natural processes and phenomena, man-made accidents) while maintaining the ability agroecosystems to recovery. "

I.B. Vlasenko interprets "environmentally safe land use" in a broad sense as the ecological rehabilitation of land resources while ensuring food security [5].

R.B. Taratula interprets ecologically safe agricultural land use in a broad sense, "as ecological improvement of the environment while ensuring food security." In a narrow sense, it defines environmentally friendly agricultural land 
use, "as the development and implementation of a system of technological, economic and legal measures for cost-effective use of agricultural land, preservation and reproduction of their productive potential" [17].

Today, scientists who study the issue of "environmentally safe land use" pay more attention to its environmental component $[10$, p. $140-141 ; 14 ; 18$, p. $92-$ 93]. However, the very term land use implies that the main purpose of this process is to obtain a social effect, which without taking into account the economic component is impossible. Therefore, the study of modern economic activity of agricultural land tenure and land use should be based on the study of criteria for the maximum possible socio-economic effect in terms of environmental requirements.

Thus, the divergence of approaches to defining the essence of the concept of "environmentally friendly agricultural land use" is due to the lack of a clearly defined concept of its formation, as well as insufficient organizational and economic support of this process.

Today, Article 50 of the Law of Ukraine "On Environmental Protection" defines the concept of environmental safety: "Environmental safety is a state of the environment in which the prevention of environmental degradation and the emergence of danger to human health" [16] .

At the same time, the same article regulates that environmental safety is guaranteed to all citizens of Ukraine by implementing a wide range of measures. Designing environmental safety requirements for the formation of agricultural land use, first of all it should be noted that the Law of Ukraine "On Land Protection" establishes that one of the main principles of state policy in land protection is "priority of environmental safety requirements in land use as a spatial basis, natural resource and fixed assets "[15]. Also, in order to ensure the environmental safety of the citizens of Ukraine, rationing and standardization in the field of land protection and soil fertility reproduction is carried out. 
Interpretation of the essence of the concept of "environmentally safe agricultural land use" is appropriate because of its understanding as a security situation of vital social and personal interests and the environment of the rural areas, aimed at protecting against possible and potential threats and risks caused by non-compliance with agricultural land regulations. The concept of environmental safety through the prism of economic doctrinal affiliation should be understood as an orderly system of relations between economic entities and residents of the territory in terms of rational use of natural resources and ensuring the quality of the environment. Some areas of influence and interaction of environmental and economic components of agricultural land use security are presented in the picture 2 .

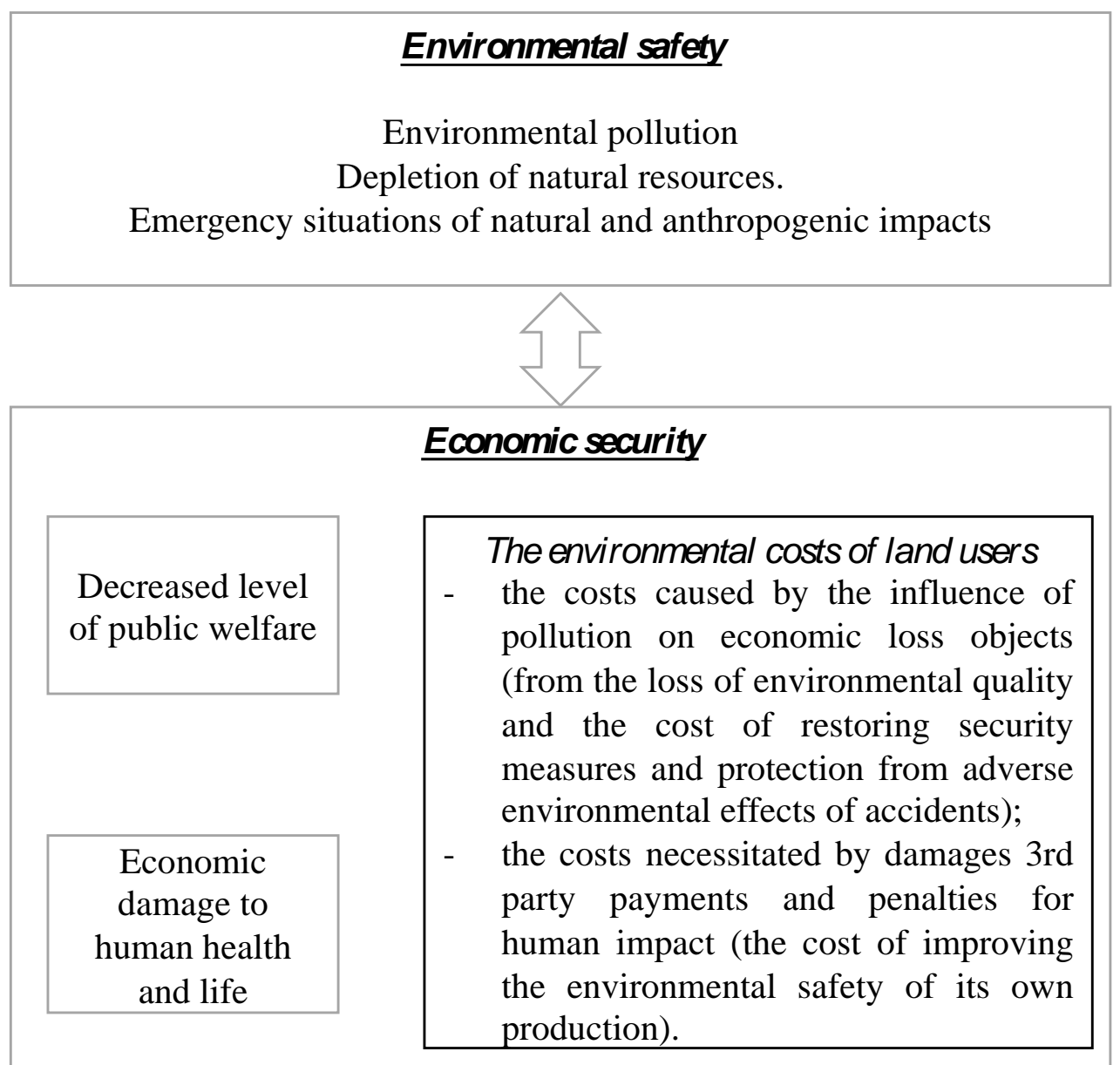




\section{Picture 2. Directions of influence of interaction of ecological and economic components of safety of agrarian land use}

Source: formed by the author on the basis of $[2 ; 3 ; 9 ; 13 ; 20]$.

The issue of assessing the ecological safety of agricultural land use should be studied only in view of the conceptual dominants of such safety, where the determining factor is the qualitative characteristics of agroecosystems, which are ensured by its key function - the ability to reproduce and restore. In this regard, it is most appropriate to use the impact of anthropogenic pressure on agricultural land use on the biosphere and its level, which ultimately affects the reproductive capacity of the agroecosystem.

Given the different concepts of the relationship between economic development and environmental security (sustainability, balance, rationality, etc.), as well as given the specifics of the agricultural sector, the essence of environmentally friendly agricultural land use can be interpreted as a process of land use that guarantees health hazards. prevention of environmental degradation of agro-ecosystems and degradation of land resources, as well as their resilience to environmental threats and risks.

Conclusions. Based on the above definition, the process of environmentally friendly agricultural land use necessarily involves the formation of environmentally friendly agricultural land holdings and land uses, ie those that allow to ensure environmental safety in their spatial (location, area, configuration, structure and composition of land) and economic (technology, equipment, means of production, etc.) parameters, while ensuring maximum production efficiency. Therefore, the regulation of existing land tenure and land use in the direction of ensuring environmental safety should not be considered in isolation, but in the general system of agricultural land use, as the formation of a new business entity may affect a number of other farms or landowners. 


\section{Reference}

1. Atamanyuk O.P. (2013) Udoskonalennya terytorial'noho zemleustroyu zemel' sil's'kohospodars'koho pryznachennya [ Improvement of territorial land management of agricultural lands]V isnyk Zhytomyrs'koho natsional'noho ahroekolohichnoho universytetu. 1-2(2), 45-52.

2. Bavrovs'ka N.M., Martyn A.H. (2012) Ekoloho-ekonomichne obgruntuvannya ratsional'noho zemlekorystuvannya terytorial'nykh sotsial'no-pryrodnykh kompleksiv rehionu: nauk. monohr. [Ecological and economic substantiation of rational land use of territorial social and natural complexes of the region: science. monograph ] , [in Ukrainian], Kyiv, 307

3. Barvins'kyy A. (2013) Ekoloho-ekonomichni aspekty formuvannya staloho sil's'kohospodars'koho zemlekorystuvannya $\mathrm{v}$ rynkovykh umovakh [ Ecological and economic aspects of the formation of sustainable agricultural land use in market conditions]. Zemlevporyadnyy visnyk.2. 50-53.

4. Budzyak O.S. (2011) Ekolohobezpechne vykorystannya zemel': teoretychni ta praktychni aspekty: monohrafiya. [Ecologically safe use of lands: theoretical and practical aspects: monograph], [in Ukrainian], Kyiv, 326

5. Vlasenko I.V. (2011) Ekoloho-ekonomichna bezpeka rozvytku ahrosfery Ukrayiny: monohrafiya. [ Ecological and economic safety of development of agrosphere of Ukraine: monograph] , [in Ukrainian],Vinnytsya, 388

6. Dobryak D.S., Kuzin N.V. (2016) Ekoloho-ekonomichne otsinyuvannya protsesiv, shcho sprychynyuyut' dehradatsiyu zemel'nykh resursiv [Ecological and economic assessment of processes that cause degradation of land resources] Zbalansovane pryrodokorystuvannya.2. 105-113.

7. Khvesyk M.A.(2014) Ekolohichna i pryrodno-tekhnohenna bezpeka Ukrayiny v rehional'nomu vymiri [Ecological and natural-technogenic safety of Ukraine in the regional dimension: monograph] Instytut 
ekonomiky pryrodokorystuvannya ta staloho rozvytku NAN Ukrayiny, 340

8. Yeremenko D.V. (2001) Ekolohichna bezpeka - neobkhidna vymoha funktsionuvannya APK Ukrayiny [ Ecological safety is a necessary requirement for the functioning of the agro-industrial complex of Ukraine] Naukovyy visnyk ahrarnoyi nauky Prychornomor"ya Mykolayivs'koyi derzhavnoyi ahrarnoyi akademiyi. Mykolayiv,165-167.

9. Kalinchyk M.V. (1997) Naukovi osnovy ekonomichnoyi adaptatsiyi sil's'koho hospodarstva do navkolyshn'oho seredovyshcha. [Scientific bases of economic adaptation of agriculture to the environment ] [in Ukrainian] ,263.

10.Kryvov V.M. (2008) Naukovo-metodychne obgruntuvannya ekolohichnobezpechnykh zemlekorystuvan'. [Scientific and methodical substantiation of ecologically safe land uses ] [in Ukrainian], 538.

11.Kupinets' L.YE., Zhavnerchyk O.V. (2016) Ekolohichna bezpeka ahrarnoho zemlekorystuvannya: teoriya i mekhanizmy zabezpechennya: monohrafiya. [Ecological safety of agrarian land use: theory and mechanisms of maintenance: monograph ], [in Ukrainian], 316, 149

12.Kupriyanchyk I.P., Dorosh O.S. (2012) Informatsiyno-metodychne zabezpechennya ekolohobezpechnoho vykorystannya sil's'kohospodars'kykh uhid'. Investytsiyi: praktyka ta dosvid. 2012. № 5. S. 69-70.

13.Kupriianchyk, I. (2020), "Theoretical and methodological foundations of the organizational and economic support of ecologically safe agricultural land use", Efektyvna ekonomika, [Online], vol. 3, available at: http://www.economy.nayka.com.ua/?op=1\&z=8276

14.Kaz'mir P.H., Stoyko N.Y.(2009) Orhanizatsiya sil's'kohospodars'koho vykorystannya zemel' na landshaftno-ekolohichniy osnovi: monohrafiya 
[Organization of agricultural land use on a landscape-ecological basis: monograph ] [in Ukrainian], 254.

15.Law of Ukraine on the about land protection № 962-IV. (2003, June 19). Available at: https://zakon.rada.gov.ua/laws/show/962-15.

16. On the protection of the natural environment: Law of Ukraine (1991) Available at: http://zakon2.rada.gov.ua

17.Taratula R. B. (2019) Informatsiyne zabezpechennya systemy zbalansovanoho zemlekorystuvannya $\mathrm{v}$ Ukrayini: monohrafiya. [Information support of the system of balanced land use in Ukraine: monograph.], [in Ukrainian], 304.

18.Tretyak A.M. ( 2012) Ekolohiya zemlekorystuvannya: teoretykometodolohichni osnovy formuvannya ta administruvannya. [Ecology of land use: theoretical and methodological bases of formation and administration] Kherson, [in Ukrainian], 440.

19.Ul'yanchenko O.V., Petrenko O.YA., Myrhorod M.M. (2015) Orhanizatsiya zemel'nykh uhid' na ahrolandshaftniy osnovi: ekolohoekonomichni aspekty: monohrafiya. [ Organization of land on an agrolandscape basis: ecological and economic aspects: monograph],Kharkiv, [in Ukrainian], 236 .

20.Shvorak A., Yevsyukov T. ( 2014 )Sposoby ta metody konsolidatsiyi zemel' sil's'kohospodars'koho pryznachennya [ Methods and methods of consolidation of agricultural land]. Ekonomist, 44-48.

21.Shkuratov O.I. (2016) Orhanizatsiyno-ekonomichni osnovy ekolohichnoyi bezpeky v ahrarnomu sektori Ukrayiny: teoriya, metodolohiya, praktyka [Organizational and economic bases of ecological safety in the agrarian sector of Ukraine: theory, methodology, practice], [in Ukrainian], 356. 
Купріянчик І.П.

\section{СУТНІСТЬ ТА РОЛЬ ЕКОЛОГОБЕЗПЕЧНОГО АГРАРНОГО ЗЕМЛЕКОРИСТУВАННЯ В СІЛЬСЬКОМУ ГОСПОДАРСТВІ}

Анотація. Стаття присвячена питанням взаємозв’язку економічного
розвитку та екологічної безпеки довкілля.
Стосовно аграрного землекористування забезпечення екологічної безпеки передбачає оптимізацію організації землекористування та процесу використання земель на основі екологічних обмежень забруднення довкілля і сільськогосподарської продукції. Перш за все, відповідно до екологічних обмежень визначаються можливості експлуатації природних ресурсів та врахування особливостей агроекосистем (природно-кліматичні умови, водні ресурси, рельєф місцевості, структура земельних угідь та грунтів, рівень ерозії земель тощо) для вирішення проблем забезпечення продовольчої безпеки. На їх основі здійснюється екологічно збалансована експлуатація агроекосистем через формування екологобезпечних землекористувань, що передбачають оптимізацію господарської діяльності аграрних товаровиробників з урахуванням екологічних обмежень.

У статті, 3'ясовано сутність і значення екологобезпечного аграрного землекористування в сільському господарстві, запропоновано підхід до визначення сутності екологобезпечного аграрного землекористування як процесу використання земель в аграрному секторі економіки, за якого забезпечується запобігання небезпеки для здоров'я людини, попередження погіршення екологічного стану агроекосистем та деградації земельних ресурсів, а також їх стійкість до екологічних загроз та ризиків. Визначено роль екологобезпечного аграрного землекористування в забезпеченні сталого розвитку сільських територій та напрями впливу взаємодії екологічної та економічної складових безпеки аграрного землекористування

Ключові слова. Екологобезпечне аграрне землекористування, сільське господарство, економічний розвиток, сталий розвиток. 
Куприянчик И.П.

\section{СУЩНОСТЬ И РОЛЬ ЭКОЛОГОБЕЗОПАСНОГО АГРАРНОГО ЗЕМЛЕПОЛЬЗОВАНИЯ В СЕЛЬСКОМ ХОЗЯЙСТВЕ}

Аннотация. Статья посвящена вопросам взаимосвязи экономического развития и экологической безопасности окружающей среды. Относительно аграрного землепользования обеспечения экологической безопасности предусматривает оптимизацию организации землепользования и процесса использования земель на основе экологических ограничений загрязнения окружающей среды и сельскохозяйственной продукции. Прежде всего, согласно экологических ограничений определяются возможности эксплуатации природных ресурсов и учета особенностей агроэкосистем (природно-климатические условия, водные ресурсы, рельеф местности, структура земельных угодий и почв, уровень эрозии земель и т.д.) для решения проблем обеспечения продовольственной безопасности. На их основе осуществляется экологически сбалансированная эксплуатация агроэкосистем через формирование экологобезопасных землепользования, предусматривающие оптимизацию хозяйственной деятельности аграрных товаропроизводителей с учетом экологических ограничений.

В статье, так же выяснено сущность и значение экологобезопасного аграрного землепользования в сельском хозяйстве, предложен подход к определению сущности экологобезопасного аграрного землепользования как процесса использования земель в аграрном секторе экономики, при котором обеспечивается предотвращение опасности для здоровья человека, предупреждения ухудшения экологического состояния агроэкосистем и деградации земельных ресурсов, а также их устойчивость к экологическим угроз и рисков. Определена роль экологобезопасного аграрного землепользования в обеспечении устойчивого развития сельских территорий и направления влияния взаимодействия экологической и экономической составляющих безопасности аграрного землепользования.

Ключевые слова. Екологобезопасное аграрное землепользование, сельское хозяйство, экономическое развитие, устойчивое развитие. 